\title{
ON THE CONSTRUCTION AND RESULTS OF WORKING OF THE LARGE STEAM DREDGERS ON THE CLYDE.
}

BY Mr. ANDREW DUNCAN, OF GLASGOW.

The improvements in the channel of the river Clyde were commenced in 1770 , under the direction of $\mathrm{Mr}$. Goulbourne of Chester. At that time the navigable depth to Glasgow was only 3 feet at high water spring tides, as shown in the diagram, Fig. 7, Plate 52, with $1 \frac{1}{2}$ feet at low water ; while the high water of neap tides did not reach Glasgow at all. The river was crossed by seven fords, one being as far down the river as Dumbuck, about 12 miles below Glasgow, which had only 2 feet depth over it at low water. The first operation seems to have been the removal of the Dumbuck ford; and numerous cross jetties were afterwards shot out from either bank as far up as Glasgow, for the purpose of narrowing the channel, their outer ends being subsequently connected by parallel dykes. Soon after 1798 a few ploughs and a dredging machine worked by manual labour were employed in deepening the shallowest places; and the result of these operations was to enable vessels drawing 6 feet of water to come up to Glasgow at high water spring tides.

By the introduction of Steam Dredgers upon the Clyde, very important improvements have been effected in enlarging the channel of the river. In 1824 the first steam dredging machine was obtained, which now belongs to the town of Dumbarton, and is at work on the river Leven running out from the foot of Loch Lomond into the Clyde. By that time the Liverpool traders were coming up to Glasgow at high water spring tides, drawing 11 feet of water, as shown in the diagram, Fig. 8, Plate 52. In 1831, there were two vessels drawing 13 feet; in 1836, six vessels drawing 15 feet; in 1889, one drawing 17 feet; in 1853, two drawing 19 feet; in 1860, eight drawing 19 feet; and in 1863, two 
vessels drawing 21 feet arrived at Glasgow, illustrated by the diagram, Fig. 9, Plate 52. The register tonnage of the vessels arriving and departing from Glasgow now exceeds three millions annually; and the minimum depth of the river is now not less than 12 feet at low water, with a rise of 9 feet at average spring tides and 7 feet at neap tides. The deepening and widening of the channel is still in progress, and more powerful machinery is in course of constraction in order to hasten on the work. The depth which is now contemplated throughout the whole length of the river up to Glasgow is 15 feet at low water, giving 24 feet depth of high water at spring tides and 22 feet at neap tides.

As regards the deposit to be removed from the river bed, the greater portion of it comes from the drainage of the city, all the sewers of which discharge into the harbour, where the deposit lodges: also a considerable quantity of sand is bronght down from the upper reaches of the river by the land floods, and lodges chiefly above Glasgow bridge. One of the two large double dredging machines is kept constantly at work in the harbour, the maintenance of which costs about $£ 11,000$ annually, and three fourths of this amount may be said to be due to city sewage.

The entire dredging plant of the river consists of two large double dredgers, shown in Plates 49 to 51 , and three single dredgers, making five in all: connected with which there are 350 punts, each capable of carrying 8 cubic yards or 10 tons of material; one tug steamer of 80 horse power; and four screw hopper barges, each capable of carrying 300 tons, shown in Plates 54 and 55. During the last twenty years, $8,114,872$ cubic yards or $10,143,590$ tons of material have been removed by dredging; last year's work, ending June 1864, being 632,272 cubic yards or 790,340 tons.

The following is a general description of the two large double dredgers, Nos. 1 and 6, the latter of which is shown in Plates 49, 50 , and 51 .

The first double dredger, No. 1, was constructed in 1851 by Messrs. Murdoch Aitken and Co. of Glasgow. The hull is of iron, $38 \frac{1}{2}$ feet long, 31 feet broad, and 10 feet deep, drawing 5 feet of 
water. The engine is a direct-acting marine engine, with cylinder 37 inches diameter and 3 feet stroke, and makes about 33 revolutions per minute. The boiler is a flue boiler with four furnaces, worked at a pressure of 4 lbs. above the atmosphere, and burning abont $44 \mathrm{cwts}$. of coal per day of 10 hours. The bucket frames are of timber, trussed with iron rods, and the buckets can dredge in $22 \frac{1}{2}$ feet depth of water. The buckets are 38 in number in each well, and each contains when quite full $3 \frac{1}{2}$ cubic feet. The motion is communicated from the engine to the upper tumbler by cast iron shafting. The tumbler makes about $6 \frac{1}{2}$ turns per minute, or 13 buckets per minute; but as the buckets are never quite full, the quantity lifted when working in good material is about 10 tons in 4 minutes, or about 2 cubic feet per bucket. Taking the year ending June 1864, the total quantity of material lifted by this dredger was 143,360 cubic yards or 179,200 tons; and as the total number of engine hours was 2483 , the average quantity lifted per day of 10 hours was about 720 tons.

The material is discharged over the stern of this dredger, which arrangement was preferred to discharging at the sides inasmuch as less room is occupied in filling the punts by discharging over the stern; but this plan has the disadvantage of causing a loss of time while the punts are being shifted after each has been filled. Another disadvantage is that when working during flood tide in the lower reaches of the river, where the current is mach stronger than in the harbour, the punts become nearly unmanageable, the current forcing them so hard against the stern of the dredger, which is always moored with its bow up-stream, as to render the shifting of the punts when filled a work of considerable labour; so much so in fact that working on the flood tide in the lower reaches of the river was avoided as much as possible.

The cost of this dredger was $£ 8500$. The crew required to work the dredger and punts consists of eighteen in all, namely :captain, mate, engineer, fireman, bow craneman, sternman, wellman, two deckhands, cook, watchman, and seven men connected with the punts. The expenses of working during the year ending 30th June 1863 were:-- 


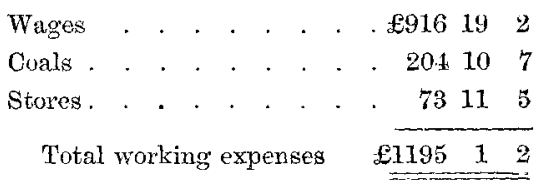

and the average annual cost of repairs is about $£ 580$.

The other large double dredger, No. 6 , shown in Plates 49 to 51 , was constructed in 1855 by Messrs. Thomas Wingate and Co. of Glasgow; and is arranged so as to discharge over the sides, in order to obriate the complaints brought against the previous dredger when working in the lower reaches of the river, for which this one was principally intended and is generally used. The crew required to work this dredger, exchasive of the crews on board the screw hopper barges, is twelve in all, namely:--eaptain, engineer, fireman, mate, cook, watchman, and six deckhands. Previous to the hopper barges being substituted for the small punts, this machine required a crew of twenty-one. The expenses of working during the year ending June 1863, the hopper barges being used, amounted to:-

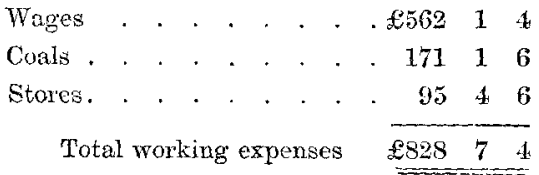

The annual average cost of repairs is about $£ 980$, being considerably more than in the case of No. 1 dredger; for as the latter is working in soft soapy sludge, the buckets and linlss do not get cut up so soon as if working in sand, as in the case of No. 6 .

Fig. 1, Plate 49, is a longitudinal section of No. 6 Dredger; and Fig. 2, Plate 50 , a plan, showing the line of punts on each side of the dredger. Fig. 3, Plate 51, is a transverse section to a larger scale.

The dredger is built entirely of iron, and is 120 feet long and 33 feet broad, with a flat bottom and 5 feet draft of water; the plates are 7-16ths inch thick at the bottom and 5-16ths inch at the sides. The two boilers $A$ A, Figs. 1 and 3, Plates 49 and 51 , fixed in the centre of the vessel, are low pressure cylindrical flue boilers, 
6 feet diameter and 15 feet long, working at 3 lbs. pressure above the atmosphere; and the coal consumed is about $2 \frac{1}{2}$ tons per day of 10 hours. The engine $B$ is a single side-lever condensing engine, with 37 inch cylinder and 3 feet stroke, running at an arerage speed of about 32 revolutions per minute, and driving the tumbler shafts $\mathrm{CC}$ of the two bncket frames $\mathrm{DD}$ at the reduced speed of 6 revolutions per minute, by two sets of spur gearing consisting of mortice wheels and cast iron pinions. Either set of buckets can be stopped and started independently of the other by means of clutch boxes worked by levers upon deck.

The power is communicated to the tumbler shafts $\mathrm{C} \mathrm{C}$ through friction wheels $\mathrm{E} \mathrm{E}$, which are adjusted so as to transmit only a definite amount of power, and to slip round freely whenever the resistance exceeds that limit, from the buckets cutting too deeply into the ground or meeting with any obstacle: by this means any risk of damage to the machinery is prevented. One of these friction wheels is shown enlarged in Figs. 4 and 5 , Plate 52. It consists of one ring revolving within another, the inner one $\mathrm{F}$ being keyed upon the shaft, and having a cylindrical recess of rectangular section turned in the circumference, $8 \frac{1}{2}$ inches wide and 1 inch deep, in which fit a series of cast iron segment blocks II. These are held in recesses in the outer ring $G$, and are each pressed against the inner ring by a set serew, adjusted to give the required amount of friction for driving the imer ring $F$ and the gearing connected with it.

The bucket frames or dredging ladders D D, Plates 49 and 51, consist each of a pair of wrought iron plate girders, 77 feet long and 3 feet 9 inches deep in the centre, fixed parallel to each other with 2 feet 3 inches space between them, and stayed together by transverse plate stays. A transverse section of one of the bucket frames is shown in Fig. 6, Plate 52. These frames carry a series of cast iron rollers, upon which the bucket links travel; and a cast iron tumbler $\mathrm{C}$ and $\mathrm{H}$, Fig. 1, at the top and bottom ends, over which the links work. Each ladder is suspended at the upper end by cast iron dead-eyes, firmly bolted to the main framing of the dredger; through these dead-eyes the upper tumbler shaft $\mathrm{C}$ passes freely, and round 
them the ladder turns in being lifted or lowered: thus the upper tumbler shaft $\mathrm{C}$ does not bear any part of the weight of the ladder $\mathrm{D}$. The shaft $\mathrm{C}$ is of wrought iron, and works in top and bottom brass bushes in pillow blocks bolted to the main framing of the dredger. Fiach ladder works in a vertical well $\mathrm{K}$, Figs. 2 and 3, passing through the bottom of the vessel.

There are 41 buckets to each ladder, one of which is shown separately in Plate 53; Fig. 10 is a vertical section, Fig. 11 a plan of the back, and Figs. 12 and 13 transverse sections at the mouth and at the bottom. The buckets are constructed of 5-16ths inch wrought iron plates, bent and rivetted, with a flat back $\frac{1}{2}$ inch thick, upon which four wrought iron bars $J J$ are rivetted, having eyes at the ends. These are connected together by the two intermediate links L L, 3 inches square, and jointed with $2 \frac{1}{4}$ inch steeled pins, the whole forming a continuous chain with 2 feet pitch of the links. The pins are prevented from turning in the eyes of the bucket links J, which are not steeled, and the eyes of the intermediate links $L$ are bushed with steel on the wearing side. In another dredger, No. 7, which is the most recent construction, the plan is adopted of inserting a bush of hard steel 5-8ths inch thick into the eyes of the single links $\mathrm{L}$, while they are hot; and when worn this bush is driven out and another inserted, so that the eyes of the links do not wear at all. The mouth of the bucket is made $1 \frac{1}{4}$ inch thick at the point, tapered to $\frac{1}{2}$ inch at the sides, and is faced on the outside with steel $\frac{1}{2}$ inch thick welded on the plate, as shown by the darker section in Figs. 10 and 12 ; the month is shaped in a projecting scoop form, for excavating and lifting the material dredged, as each bucket in succession passes under the bottom tumbler $H$ of the ladder, Figs. 1 and 3.

The depth of excavation of the buckets is regulated by the lifting chain M, Fig. 1, Plate 49, attached to the lower end of the bucket frame $\mathrm{D}$, and hoisted at the rate of about 26 feet per minute by the windlass or hoisting barrel $\mathrm{N}$, which is driven by a small shaft from the engine through a clutch box and friction wheel, similar to those giving motion to the buckets and also worked 
by a lever upon deck. The depth of dredging is continually gauged during work by a man stationed at the bucket well $\mathrm{K}$ holding a gauging rod resting on the river bottom, and having the lifting lever at hand and also a break handle for lowering the bucket frame, so as to keep the buckets constantly adjusted to a uniform depth of cut, according to the surface of the ground. A selfindicating gange has also been fitted up on deck, so that the captain by glancing at the position of the bucket frame may in an instant tell at what depth below the surface of the water the points of the buckets are working. The greatest depth the dredger can work at is about 28 feet.

The forward motion for the cutting of the buckets is given by the bow chain $O$, Plates 49 and 50, which is 1 inch diameter, attached to a single-fluked anchor weighing $12 \mathrm{cwts}$. placed about 600 feet ahead of the dredger when at the commencement of a cut. The chain is hauled in with a slow motion by the windlass $\mathrm{P}$, driven by a second small shaft from the engine through a clutch box and friction wheel, and having a set of change wheels for the purpose of regulating the rate of advance according to the nature of the material that is being excavated. This rate of advance varies from about $4 \frac{1}{2}$ feet per minute in soft sand to $1 \frac{1}{2}$ feet per minute in hard material. The dredging is done in parallel cuts of about 120 feet length. A corresponding windlass with two mooring chains $R$ at the stern of the vessel gives the means of drawing back the dredger to commence a second line of excavation parallel to the former one: this windlass is driven by a small bigh pressure donkey engine with a pair of 12 inch cylinders, the dredging engine and machinery standing still during the time occupied in going astern, which is about 15 minutes, the speed being about 8 feet per minute. The two side warp lines S S, Fig. 2, extending from each side of the dredger, serve to steady it constantly during the progress of each cut, and to shift its position into the new line of excavation; they are worked by the surging heads $\mathrm{T} T$, driven by the engine, or by hand power when required. The kedge anchors for these side warps are placed forwards of the dredger, so that the warp lines shall be somewhat in the position shown in the plan, 
Fig. 2, when the dredger is at the commencement of a cut; the warps are also passed round leading blocks when required, since it is desirable they should be as nearly at right angles to the dredger as possible. The two warps on the side next the sailing: channel of the river are lowered or slacked out when any vessel is passing, but are immediately tightened up again when the ressel has passed.

This dredger, No. 6, has now been at work for nine years, and has not required any repairs excepting for the wear and tear of the buckets, links, and rollers, and the usual repairs on the hull, \&c. The upper tumbler however, having been found too low to allow of the shoot being placed at a sufficient height and slope for loading the large screw hopper barges, was raised $2 \frac{1}{2}$ feet higher. The steeled mouths of the buckets last for the year's work of about nine months, when the buckets require to be thoroughly overhauled and put in repair. The pins and links of the bucket chains last generally about four months, and are replaced from time to time as required; a supply of duplicates being kept ready on board for the purpose. The rollers over which the buckets travel in ascending the dredging ladder are of cast iron, 1 inch thick in the barrel, with wrought iron spindles, having $1 \frac{5}{8}$ inch journals laid with steel, which lasts about three months before being worn out; these run in small cast iron steps with hard wood caps, fixed on the top flange of the ladder, which are readily renewed when worn out, the cast iron bush lasting about two months, and the wood cap about nine months. Each bucket weighs $5 \frac{1}{4}$ cwts., and the total weight of each

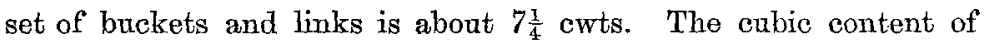
each bucket is $3 \frac{3}{4}$ cubic feet, and the average quantity of material brought up by each when working in sand is about 2 cubic feet. The number of buckets discharged per minute is 13 to 14 at the regular speed of about $6 \frac{1}{2}$ revolutions per minute of the tumbler shaft.

The total quantity of material raised per day of 10 working hours varies very much according to the nature of the material dredged. Where the dredger No. 6 is at present working, about $1 \frac{1}{4}$ mile below 
the river Leven, the rate of working is 150 tons per hour of the engine; while in hard ground the quantity may perhaps be only one half of this. Taking the entire work performed by this machine during last year, namely 303,957 tons in 2680 engine hours, the average work for a day of 10 engine hours is 1134 tons, or $113 \frac{1}{2}$ tons per hour. The total quantity of material lifted by the two large dredging machines Nos. 1 and 6 during the year ending 30th June 1864 amounts to 386,752 cubic yards, of which about 250,000 cubic yards may be considered as due to maintenance, and the remainder to the permanent widening and deepening of the channel.

The cost of dredging per cubic yard, taking the year ending 30th June 1863, as performed by No. 1 dredger, was as follows, the dredged material being conveyed away by the punts :-

Wages, coals, stores, repairs, and 5 per cent. interest 3.02 pence.

Repairs of punts . . . . . . . . . . . . 159 ,

Towing punts to and from place of deposit . . . 228 ",

Discharging punts by wagons . . . . . . . 1229 "

Total cost of dredging per cubic yard . . $\overline{19 \cdot 18}$ "

The cost of dredging as performed by No. 6 dredger during the same period, with the screw hopper barges for carrying away the material, was as follows :-

Wages, coals, stores, repairs, and 5 per cent. interest 4:06 pence.

Discharging by hopper barges-

Wages, coals, stores, repairs, and interest $\} \cdot . \cdot 2 \cdot 30$ "

Total cost of dredging per cubic yard . .

During this year No. 6 dredger was working near the two extreme ends of the river; and as during one half of the time it was attended by only two hopper barges in place of four, for discharging the material, much time was necessarily lost. This has since been rectified by the construction of additional barges.

The dredged material is disposed of according to two different modes. That filled into the 10 ton punts is towed down to some convenient part of the river, and discharged by barrows or wagons on to the banks or fields adjoining. That put into the screw hopper 
barges, shown in Plates 54 and 55, is carried down to Loch Long, beyond the mouth of the Clyde, and deposited by opening the hopper doors $U$ at the bottom of the carrying space $W$, as shown by the dotted lines in Plate 55. At the place where the deposit is made, the water is upwards of 200 feet deep, and the mouth of the loch is about 27 miles below Glasgow; the hopper barges at present at work contain each 300 tons of dredgings, and steam from 8 to 9 miles per hour. This latter mode is by far the most economical way of disposing of the dredged material, as seen by the above statement of the cost by the two methods; and the result has been so satisfactory that two additional barges are now being constructed, each to be capable of carrying 400 tons, making six barges in all. Fig. 15, Plate 55, shows the hopper barge being filled by the spout $\mathrm{V}$ from the dredger.

In conclusion it may be mentioned that a larger and more powerful single dredger, shown by the accompanying model, is now being constructed for the Clyde Trust by Messrs. A. and J. Inglis, of Glasgow. The dimensions of this dredger will be: extreme length 157 feet, extreme breadth 29 feet, depth 10 feet 9 inches, and bucket frame capable of working in upwards of 30 feet depth of water. The engine will be horizontal, with cylinder 44 inches diameter and adapted for a 3 feet stroke: the boiler will be tubular and capable of working to $25 \mathrm{lbs}$. pressure per square inch above the atmosphere. The buckets will be 39 in number, discharging over the side; the pitch of the bucket chain will be 30 inches, and each bucket when quite full will contain $13 \frac{1}{2}$ cubic feet. The flat bucket back with the double links will be made of malleable cast iron with the links cast solid upon it: this construction has been found to last without requiring repair for more than donble the time of the ordinary backs with rivetted links, shown in Plate 53. The bucket rollers will not require spindles, as they will have necks cast on the ends of the rollers, which will answer for the spindles. The lower tumbler shaft will be of wrought iron having strong rings or hoops at the journals, so that when worn the hoops can be easily removed and replaced. The only other difference of any consequence from the present dredgers will be in using grooved frictional gearing for 
driving the hoisting barrel that lifts the dredging ladder, instead of spur gearing with a friction wheel as previously described. The total cost of the dredger will be about $£ 17,000$, and it is expected to be ready early in March next.

Specimens were exhibited of the dredger buckets and links, and the bucket rollers and bearings, \&c., both new and worn ont, together with samples of the material raised in dredging; and also models of the dredger and of the screw hopper barge.

Mr. W. Smons said he had built the serew hopper barges that were used in connection with the Clyde dredgers, and it was only within the last two years that they had been adopted: previously 350 of the square punts had been required to carry away the dredged material, but four of the barges now did the work of the 120 punts formerly attending one dredger. Each barge carried 300 tons, and was 120 feet long, 24 feet beam, and drew $8 \frac{1}{2}$ feet of water when loaded; the engine was 40 horse power with 21 inches stroke, driving a screw 7 feet diameter, and the speed was the same whether loaded or empty, amounting to 9 miles per hour. The Clyde trustees contemplated abolishing the old punts altogether and employing only the screw hopper barges for removing the material dredged. The barges were loaded in about 70 minutes, and ran down the river and up Loch Long to a distance of about 50 miles from Glasgow, where the whole of the dredged material was discharged through the flap doors in the bottom. Hydraulic gearing was used to close and open the bottom flap doors in two of the barges, and in the others a common windlass had been applied, which had been found to work better. The total expenses of working the dredgers and barges were about $\& 25 s$. per day, including wages, fuel, oil, and tallow; and the result of employing the screw hopper barges had been to reduce the cost of dredging from abont 1s. per ton of material 
when the punts were used to only $4 d$. per ton with the barges, making a saving of between $\$ 19,000$ and $£ 20,000$ per annum.

By this system of dredging it might indeed be possible, he thought, to form an inland town into a seaport, such as Preston, Lancaster, Manchester, or Paris, where there was already an outlet into the sea for carrying away the dredged material; all that was required would be dredgers and barges of sufficient power and capacity for the quantity of work to be done, since the double dredgers now at work in the Clyde raised each about 1100 tons per day in regular continuous work, as stated in the paper. About the year 1800 , when the depth of the river at Glasgow was only about 3 feet at high water, the annual revenue from ships coming up the Clyde was only $£ 3320$; but in 1825 , when the river had been deepened by dredging to 12 feet, allowing vessels of 300 tons burthen to come up, the revenue had increased to $£ 9000$; while in 1863, with the depth increased to 22 feet at high water, the revenue amounted to $£ 118,000$, and the river was deep enough to float the "Black Prince" armour-plated frigate of 6000 tons burthen, built by the President, the largest ship that had yet been launched in the Clyde.

The Prestdent enquired how long it took to discharge the hopper barges through the bottom flap doors, and how the doors were arranged to be opened.

Mr. W. Srmons replied that only 4 or 5 minutes were required to discharge the whole 300 or 320 tons of material carried by the hopper barge. There were twelve doors or six pair at the bottom, hinged to the iron hopper, and lined inside with timber; and the doors were let down for discharging by releasing the chains that held them ap while the hopper was full. The chains passed over pulleys in the longitudinal iron girder which extended over the hopper from end to end.

The President enquired what part of Loch Long the material was deposited in.

Mr. W. Stmons said the barges were not confined to Loch Long in particular for depositing the material, but might go to a greater distance from Glasgow if necessary. Loch Long had been chosen 
because it was the deepest part of the channel near Glasgow, the depth being about 200 feet over a considerable portion of the loch, and the material could be deposited at any part of the loch.

Mr. W. E. NEWToN remarked that a dredging machine on a different principle had been used very successfully in different parts of the United States for many years, consisting of a large bucket fixed at the end of a long lever worked by chains; the bucket was lowered and dragged along the river bottom to fill it, and was then lifted by the lever, and swung round horizontally to the required position for discharging the stuff, which was let fall through a door in the bottom of the bucket into the barge beneath. The bucket raised abont 26 cubic feet of soil at each stroke on an average. That appeared to him a simpler contrivance than the dredging machines ordinarily used in this country, such as those described in the present paper; it was at any rate maeh less expensive, and allowed of swinging the bucket round into any position required for discharging into the barge, whereas with the ordinary dredging machines the barge had to be brought to a particular place for receiving the stuff from the spout of the dredger. The gearing for working the lever was driven by a self-acting friction clutch somewhat similar to that described in the paper, except that in the American machine the inner or driving pulley was surrounded by a bridle provided with friction blocks, which were tightened against the pulley when running forwards, but slackened in running backwards; so that the clutch simply held on in working, and was not limited to slip when the resistance exceeded a certain amount, but would transmit the whole power of the driving machinery, its only purpose being to avoid breakage from sudden jerks and to release itself for running backwards. He had seen a machine on that principle, known as the "American excavator," used experimentally some years ago on the Eastern Counties Railway in the neighbourhood of Brentwood, for excavating a cutting, and all the gearing in it was worked with friction clutches of the same kind. That description of clutch was indeed much used in America for all sorts of machinery, and was found very economical and effective in preventing breakages, by allowing the 
gearing to yield under any undue strain. He had never known it fail in transmitting the full driving power, and thought it would have some advantage over the friction wheel described in the paper.

Mr. H. Maunstax enquired whether the friction wheel in the dredger described in the paper was found effectual in work, by always slipping whenever the buckets came into too hard ground or took too deep a scoop into the soil, or met with any other obstruction.

The SECRETARY said he had seen the dredger at work in the Clyde, and the friction wheel was found to answer its purpose thoroughly. The screws of the friction blocks were adjusted originally to the pressure required for the ordinary working, and then continued unaltered, without requiring any further attention in working. He had seen the bucket frame lowered slightly below the proper working position, causing the buckets to bite gradually deeper in the bed of the river, until the resistance was just sufficient to overcome the friction of the blocks, when the buckets stopped while the driving pulley or ring continued to revolve outside the friction wheel; but on slowly raising the bucket frame again, the friction wheel gradually started again as the resistance diminished, and the whole worked with complete smoothness and readiness. The engineer working the dredger stated that the friction wheel had given no trouble, and there had not been any difficulty in keeping it adjusted exactly to the point desired for working. The same kind of friction clutch was also applied to the lifting gearing by which the end of the bucket frame was raised and lowered; so that all portions of the machinery were started and stopped quite gradually, the friction gear being continually called into action to meet the irregularities in the level and material of the bed of the river and prevent any straining of the machinery.

Mr. J. Shepherd asked whether the material raised by the dredgers was used for agricultural purposes, as a manure, and whether it had any commercial value for such purposes, since it appeared the sewage of Glasgow was all discharged into the Clyde and would therefore be deposited in the bed of the river. 
The President replied that the quantity of sewage matter deposited in the river bed formed so very small a proportion of the quantity of material raised by the dredgers, that it had never been thought to apply it as a manure, and it had no commercial value for such a purpose.

In reference to the American dredger that had been referred to, a somewhat similar apparatus was occasionally used on the Clyde at the present time in dredging alongside the wharfs in the harbour, consisting of a rake or plough fixed on the end of a long pole, which was worked from the bank by a number of men, or from a punt on the river, and was moved along the edge of the wharfs for clearing out the material from the face of the quay and removing it within reach of the dredger, in cases where the dredger could not be conveniently worked close alongside.

Mr. J. J. Binckel observed that the depth of 13 feet at low water in the Clyde at Glasgow and 22 feet at high water would gire a tidal fall of only 9 feet; and he enquired whether that was the actual tidal fall at Glasgow, since at Liverpool, on the same coast, the tidal fall was as much as 32 feet. He asked also whether there was not a risk of some portion of the material deposited in Loch Long being brought back into the river by the tides, as the loch was so close to the mouth of the Clyde: in the case of the Mersey no deposit was allowed to be made at any part of the approaches to the river, for fear of interfering with the channel.

The President explained that there were so many arms of the sea to fill near the mouth of the Clyde, and so many bends in the river itself, that the tidal wave did not come up to Glasgow in the same quantity as in the Mersey; and the rise and fall at Glasgow averaged therefore from 7 to 9 feet only, very seldom more. Loch Long was a blind arm of the sea, with no outlet at the further end, and no navigation through it, and there was very little tide in it : and as it was about 200 feet deep where the barges were discharged, there did not appear any probability of any portion of the deposit being carried back by the tide.

From the paper that had been read it was obvious that the dredging machines employed in the Clyde had been productive of 
very remarkable advantages to Glasgow. From a depth of water of only about 3 feet at the beginning of the present century, the river bed had now been deepened to about 22 feet at Glasgow at high water within the space of about 63 years. But it was since the introduction of steam navigation into the Clyde that the greatest part of this improvement had taken place. The steam tugs drawing vessels up and down the river first led to the rapid deepening of the bed by dredging; and then the increase of revenue arising from the larger burthen of the vessels trading to Glasgow afforded the means of increased expenditure upon the dredging operations: thus both the depth of the river and the advantages to the city went on increasing simultaneously.

He moved a vote of thanks to Mr. Duncan for his paper, which was passed.

The following paper was then read:- 
CLYDE DREDGERS.

Fig. 1. Longitudinal Section of Dredger.

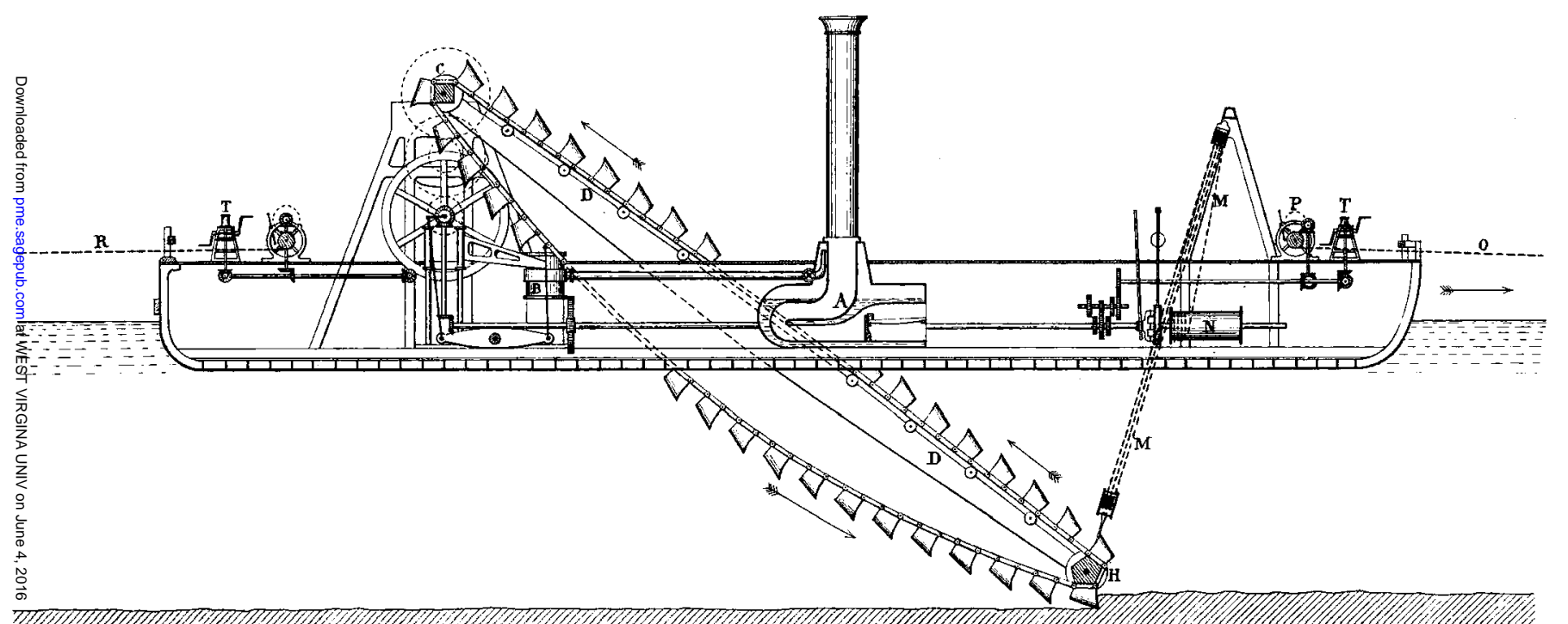

(Proceedings Inst. M.E. 1864. Page 147.)

Scale $1 / 240^{\text {th }}$

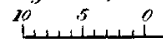

30

20

30

$\$ 0$

50

10

70

80

20 100 Feet. 


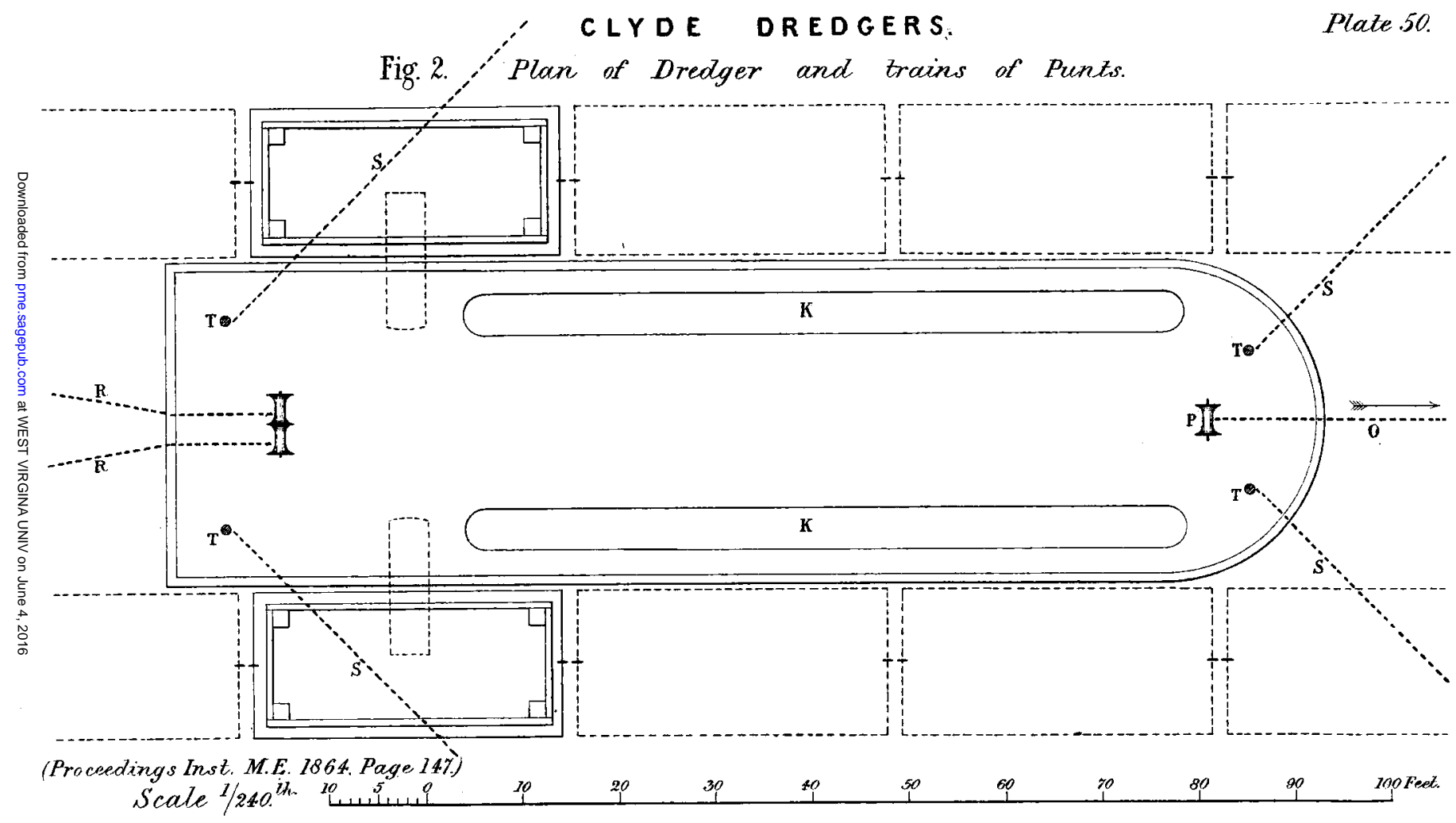


Fig. 3. Transverse Siection of Dredger.
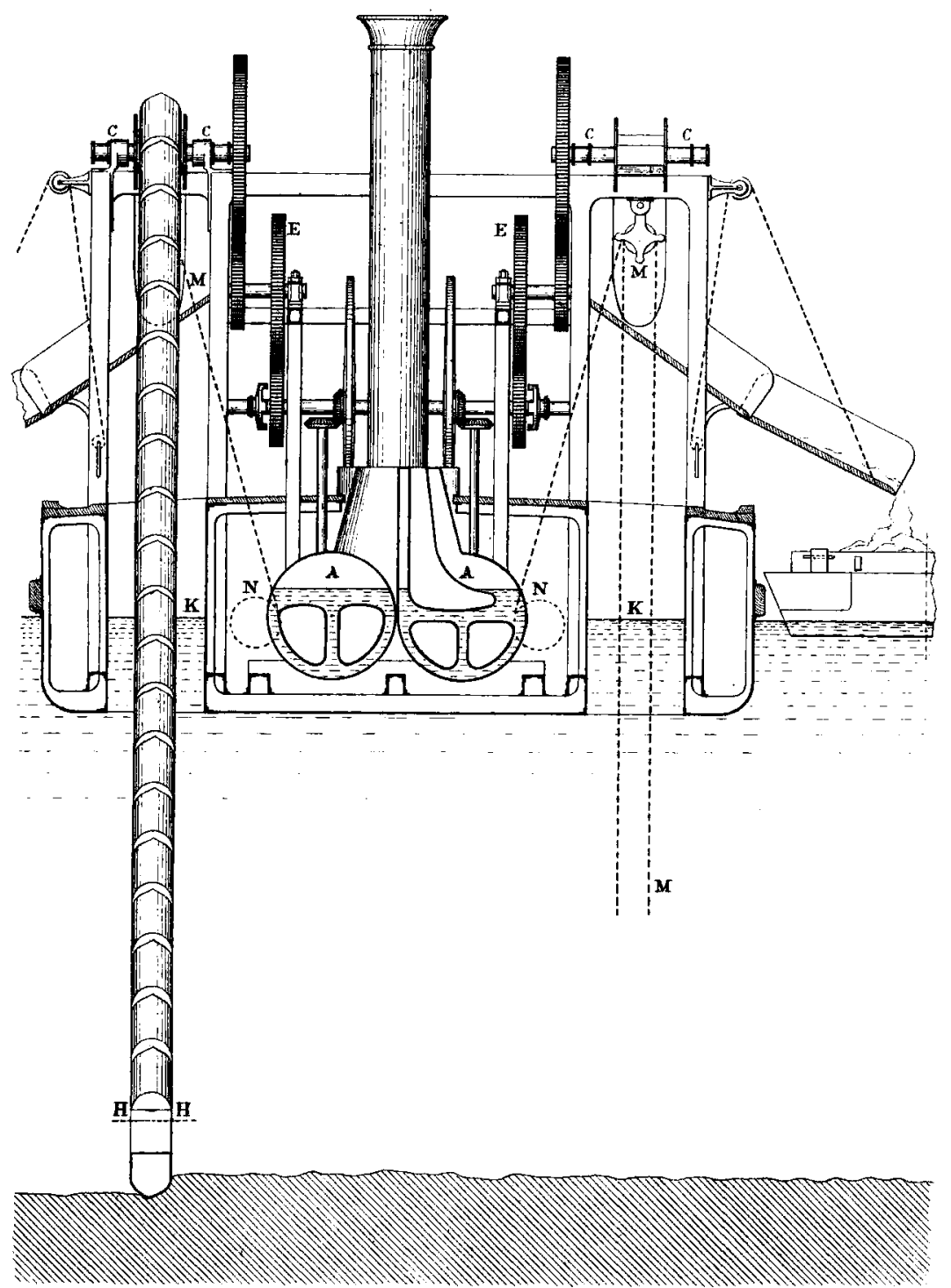
CLYDE DREDGERS .

Plate 52.

Fig. 4. Friction What. Fig.5.
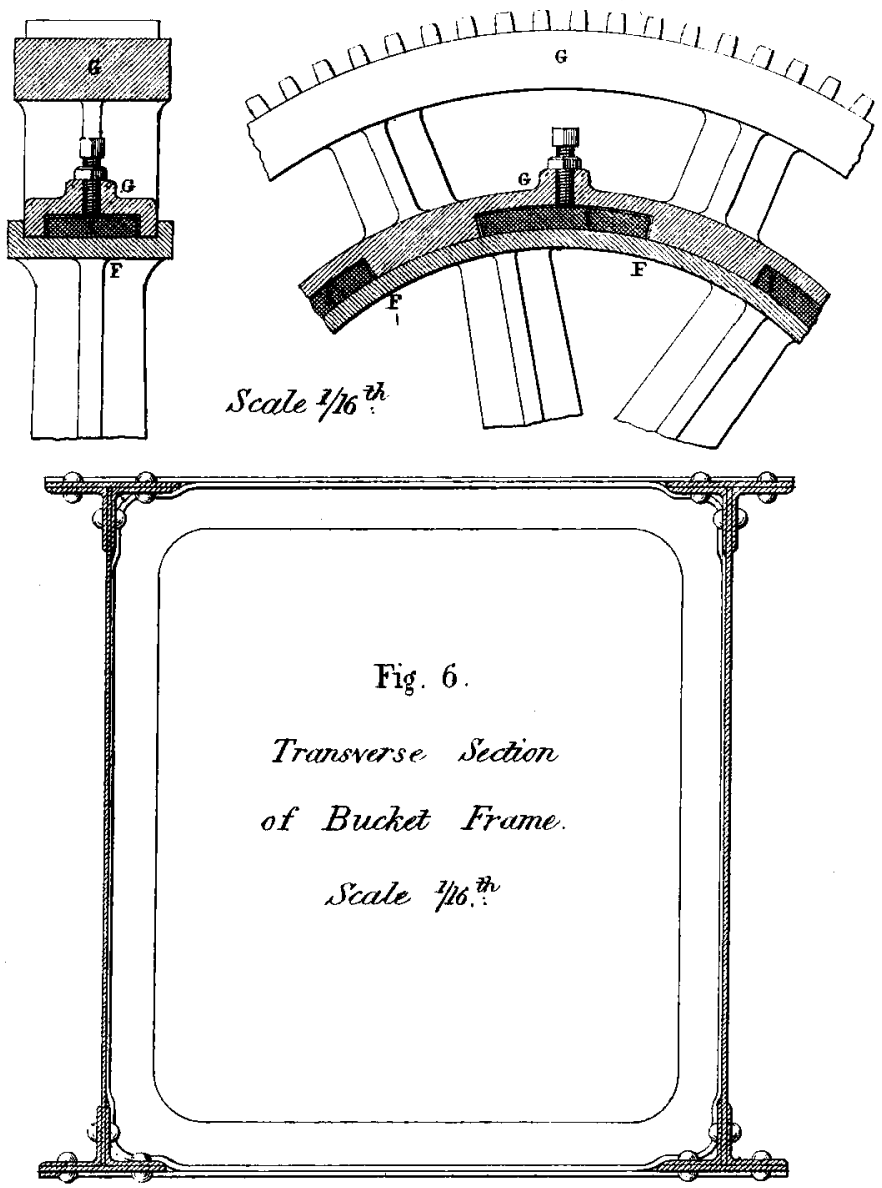

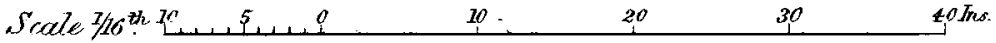

Diagram showing Despening of Clyde by Dredging.

Fig. 7

1800

Depth 3 teet.

Reverue E3320.
Fig. 8.

1825 ,

Depth 12 feet.

Reverue $\$ 9000$.

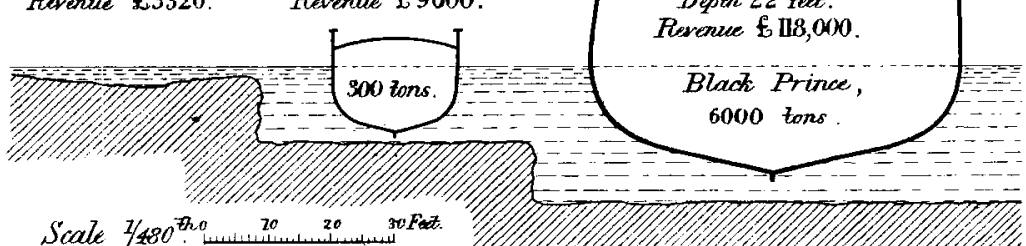

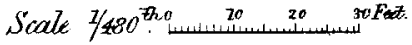

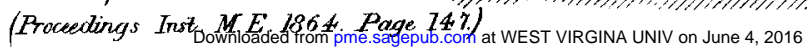


CLYDE DREDGERS.

Plate 53.

Dredger Buckets.

Fig.10. Vertical Section of Bucket:

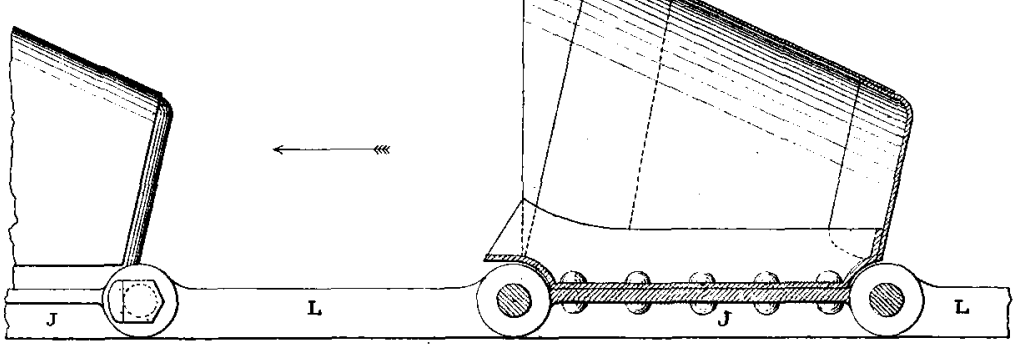

Fig.11. Plan of Back of Bucket.

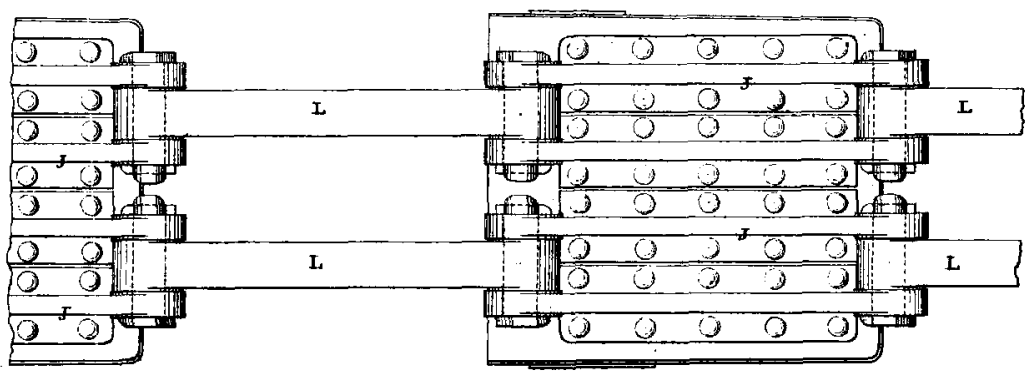

Fig.12. Tronsverse Section

at Mouth of Bucket.

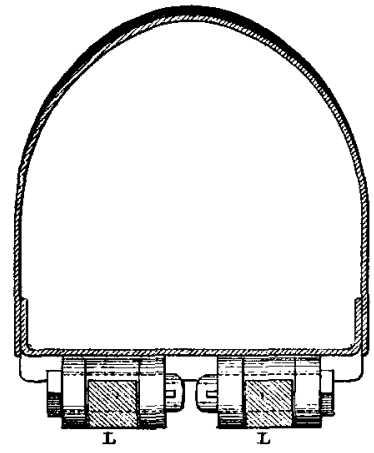

Fig. 13.

Transwerse Section at Bottom of Bucket.

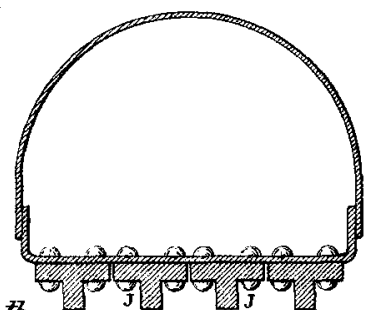

10

10

$3 i$ 40 Traties.

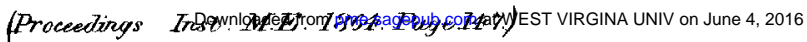




\section{CLYDE DREDGERS .}

Fig. 14. Longitudinal S'ection of Screw Hopper Barge.
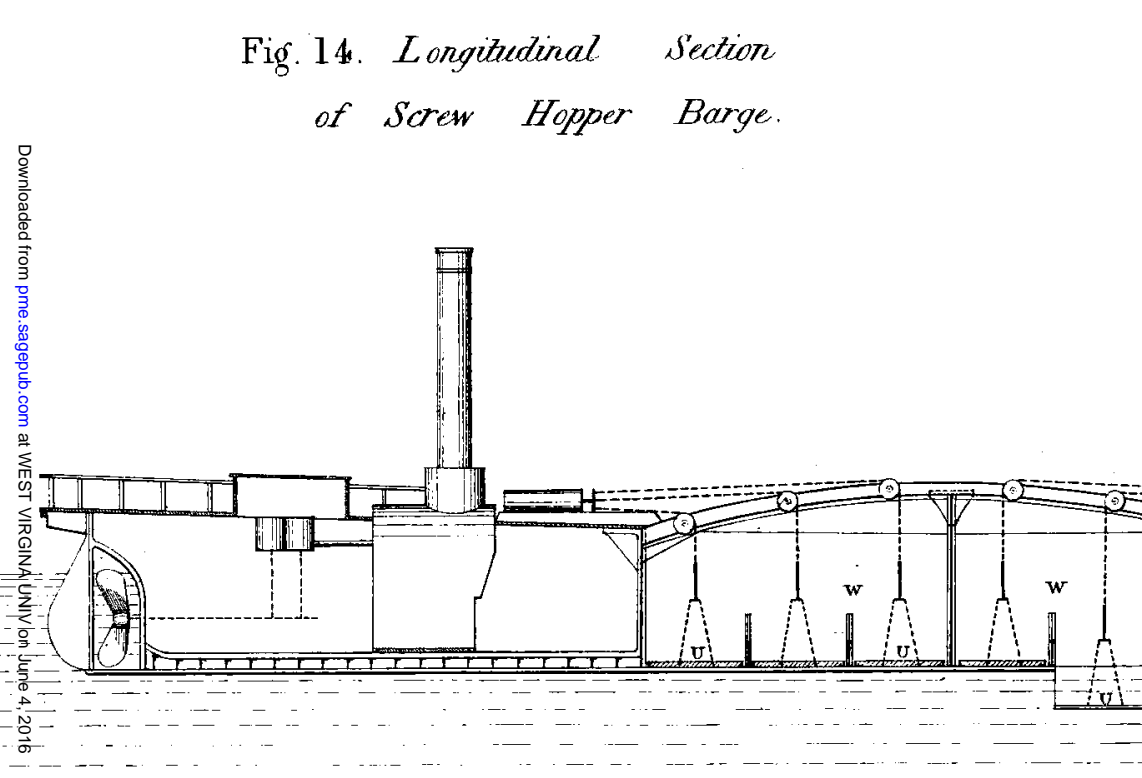

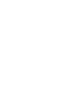

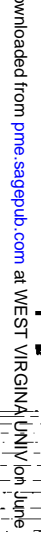

(Proceedings Inst. M.E 12644. Page 14\%) Scate $1 / 240^{z /}$ $70 \quad 5$ o

10 20 30 40 50 60 70 80 700 Fed. 
CLYDE DREDGERS.

Plate 55.

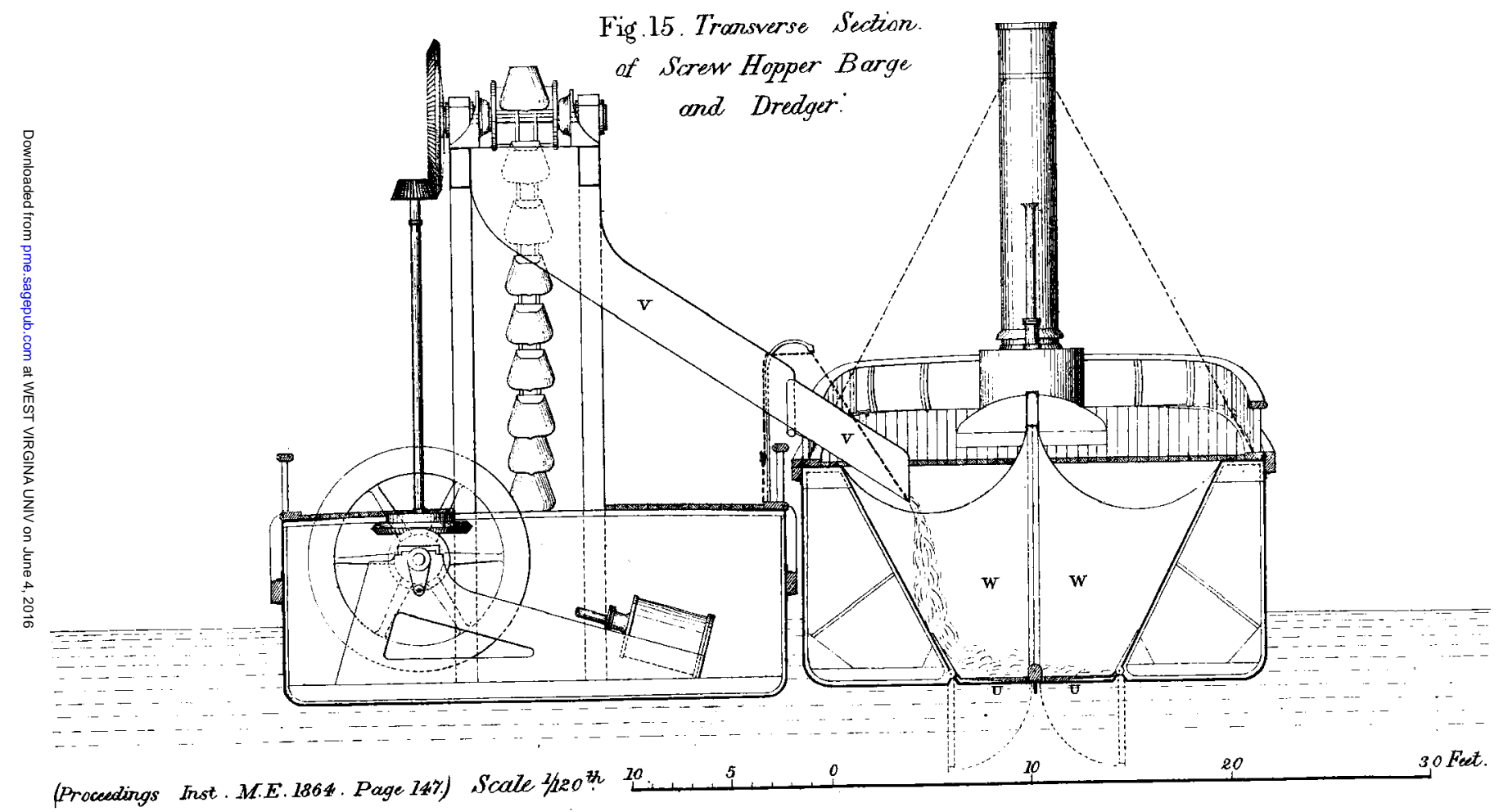

